\title{
Temporal Variation of Tropical Karst Groundwater Suitability for Irrigation in Gremeng Resurgence, Gunungsewu Karst Area, Indonesia
}

\author{
Ahmad Cahyadi ${ }^{1,2 *}$, Tjahyo Nugroho Adji ${ }^{1,2}$,Eko Haryono ${ }^{1,2}$, M Widyastuti ${ }^{1,2}$, Adityas \\ Pradana Kusuma $\mathrm{Aji}^{2}$, Muhammad Naufal ${ }^{2}$ and Indra Agus Riyanto ${ }^{3}$ \\ ${ }^{1}$ Karst Research Group, Faculty of Geography, Universitas Gadjah Mada, Yogyakarta, Indonesia \\ ${ }^{2}$ Department of Environmental Geography, Universitas Gadjah Mada, Yogyakarta, Indonesia \\ ${ }^{3}$ Lentera Geosains, Sleman, Yogyakarta, Indonesia
}

\begin{abstract}
Analysis of groundwater availability for irrigation purposes pertains to not only quantity but also quality. The characteristics of groundwater quality essentially define crop productivity and determine whether or not crops can grow. This research was designed to identify the suitability of karst groundwater for irrigation temporally (in one year), with an example of Gremeng Resurgence in Gunungsewu Karst Region, Indonesia. It drew on data on electrical conductivity and several major ions, such as potassium, magnesium, sodium, and calcium, by analyzing $\%$ sodium content $(\mathrm{Na} \%)$, Sodium Adsorption Ratio (SAR), and groundwater suitability for irrigation using the Wilcox and USSL diagrams. These analyses revealed that the water quality observed varied by seasons owing to the effects of dilution by rain and water-rock interaction in the karst region. However, this temporal variation was not substantial so that the classes of groundwater suitability only ranged between good and excellent, and the salinity hazard levels differentiated into low until medium.
\end{abstract}

\section{Introduction}

Pressure on natural resources is currently intensifying as population size grows and climate change impacts accentuate [1]. Multiplying population size must be balanced with an increase in food production [2], but, on the other hand, agricultural areas abutting urban regions continue to shrink as they have been constantly converted into built-up land. Another concerning factor associated with food production is climate change impact, including shifts in seasons, changes in rainfall intensity, and intensifying occurrences of extreme climatic phenomena.

Agricultural land with an irrigation system is among the areas on Earth that can produce food. Although it only accounts for $17 \%$ of the total agricultural land worldwide [3], the yields can reach, on average, $40 \%$ of the global foodstuff [4]. Nevertheless, this farming practice is also responsible for $70 \%$ of the total water used by humans [5], especially in arid areas where irrigation water and groundwater are the main conditions for agriculture.

* Corresponding author: ahmad.cahyadi@ugm.ac.id 
Sources of water for agricultural irrigation can be classified into three. (1) Green water includes all irrigation water coming from rainwater that is stored temporarily as soil moisture. (2) Blue water is irrigation water sourced from renewable groundwater and surface water, such as rivers, lakes, reservoirs, and wetlands. (3) Non-renewable groundwater and non-local water resources comprise all irrigation water extracted by seawater desalination installations and pumping of fossil groundwater or transported from areas with a great distance, even crossing different groundwater basins and watersheds [6]. Fossil groundwater intake for irrigation is typical in arid regions with little to no precipitation. This source is termed nonrenewable groundwater because its extraction exceeds the groundwater recharge in the region or it is not an active part of the hydrological cycle currently taking place in said region.

Groundwater is one of the main sources of irrigation water, especially in arid regions and areas with access to springs producing large discharge. Analysis of groundwater availability for irrigation, however, comprises not only quantity but also quality analysis [7]. In this context, characteristics of groundwater quality strongly determine crop productivity and the ability of crops to live and grow [8]. Besides, a full understanding of these properties is likely to encourage proper groundwater resources management for an accurate, optimum, and efficient allocation. Hydrogeochemical characteristics, which define the state of water quality, include major components in water, soil-water interaction, water-rock interaction in aquifers, dissolved minerals, and influencing anthropogenic activities and interaction time $[9,10,11,12,13]$. This is possible considering that groundwater quality characteristics are shaped by many factors, such as rainwater or precipitation chemistry, soil properties where infiltration occurs, types of cover or land use, rock constituents of the aquifer, landform genesis (prevailing geomorphological processes), the water residence time in the aquifer, and influencing human activities $[14,15,16]$.

Karst groundwater is among the water sources that agricultural irrigation can use. It especially flows from karst springs that have a relatively large discharge and fall into the category of blue water because water utilization and extraction from karst springs are unlikely to exceed the groundwater recharge in the area. However, a study in the tropical karst region in Mexico shows that from a quality standpoint, not all karst groundwater is suitable for irrigation [17]. Also, due to the development of dissolution channels, karst regions have a more dynamic groundwater quality than other landforms. In a highly developed karst area, recharge water flows into the underground river systems rapidly through ponors, sinkholes, and fissure-sized dissolution channels. Therefore, karst groundwater quality analysis needs to incorporate a multi-temporal approach for optimal groundwater utilization [18].

This study was intended to assess the multi-temporal suitability of karst groundwater, with an example of Gremeng Resurgence (Figure 1) - a spring in the Gunungsewu Karst Area. Gremeng Karst Drainage Basin plays a crucial part in irrigating rice fields in Ponjong and Karangmojo Districts, Gunungkidul Regency, the Special Region of Yogyakarta, Indonesia. As for Gremeng Resurgence, it provides water to half of the Beton-Gremeng irrigation system that covers 800 hectares of agricultural land. 

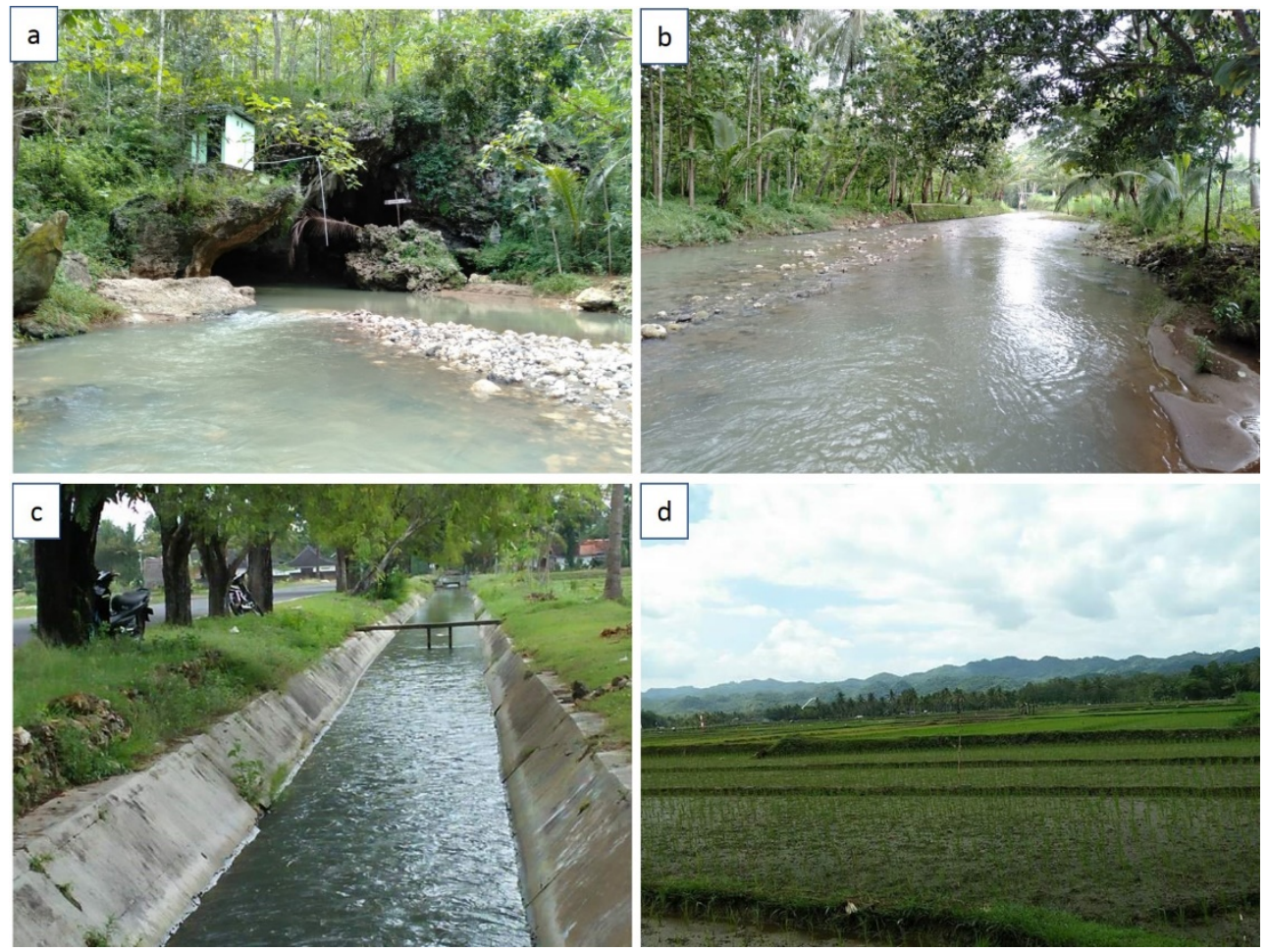

Gambar 1. (a.) Gremeng Resurgence, (b.) The River that Flow from Gremeng Resurgence, (c.) Irrigation Channels in the Beton-Gremeng Irrigation System (d.) Irrigated Rice Field in the Beton-Gremeng Irrigation System

\section{Methods}

\subsection{Research Location}

The study was conducted at Gremeng Resurgence, one of the largest springs in the Ponjong Sub-system in the Northern-Central Section of the Gunungsewu Karst Area [19] (Figure 2). Administratively, this sub-system is located on the border of the Gunungsewu Karst Area that is adjacent to the Wonosari Basin. Gremeng Resurgence, together with Concrete Resurgence, fulfills the irrigation water needs of all agricultural practices in the Beton-Gremeng irrigation system [20]. It receives water from an allogenic recharge area, approximately $13.25 \mathrm{~km}^{2}$, in the ancient volcanic region in the northern part of the Gunungsewu Karst Area.

\subsection{Materials and Methods}

Based on their focus of measurements and considerations, methods of water suitability analysis for irrigation can be broadly differentiated into four, namely (1) total dissolved salts (salinity hazard), (2) proportion of sodium ions in water to other cations, including the level of sodium hazard and its relation to soil permeability effects, (3) total alkalinity, which is generally highly associated to alkalinity concentration (calcium is combined with magnesium), and (4) concentrations of toxic elements or ions (toxicity) [21]. However, an analysis that factors in several ions, instead of just one, is more advisable [22]. Using more than one method is also suggested to produce better research outcomes and avoid errors in the measurement or content analysis that relies on just one ion. 


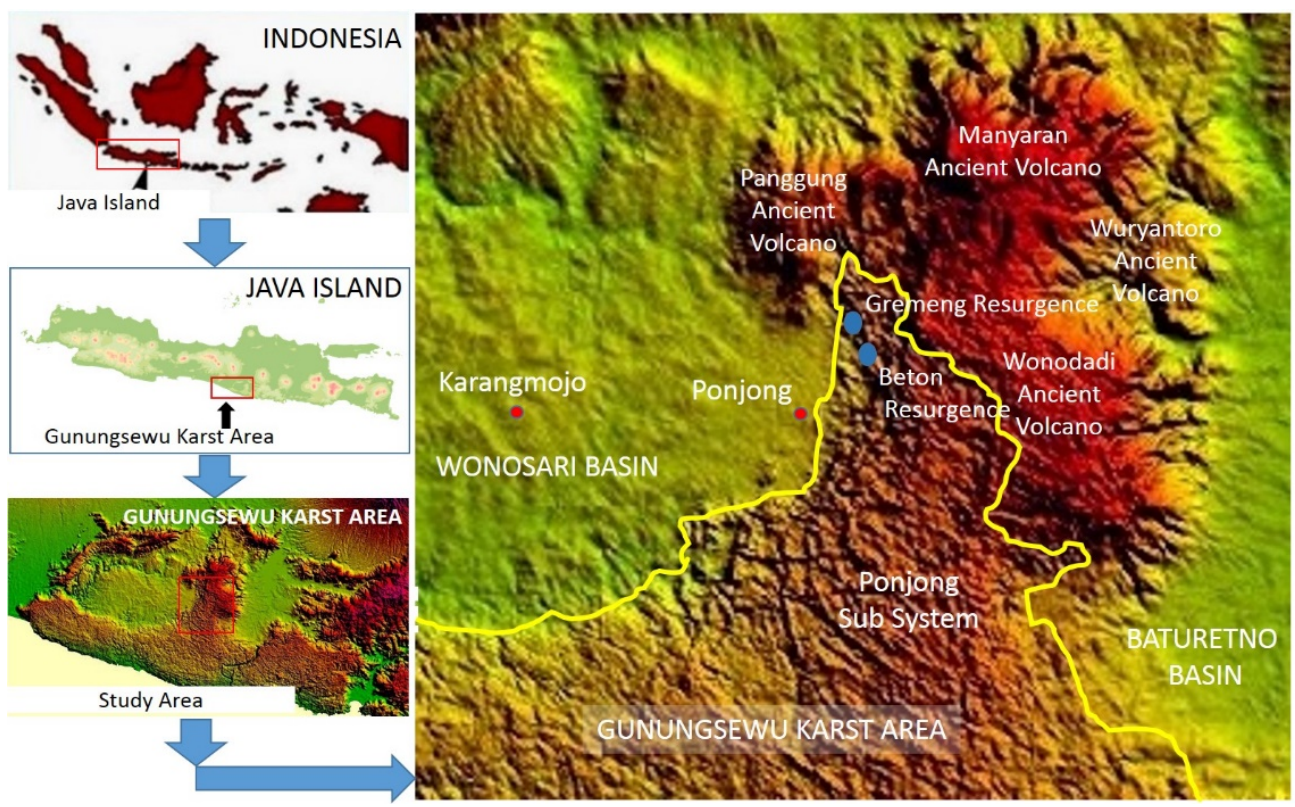

Figure 1. The Location of Gremeng Resurgence

This paper discusses the results of research that used four methods, namely (1) percentage of sodium content (Na\%), (2) Sodium Adsorption Ratio (SAR), (3) Groundwater suitability analysis for irrigation with Wilcox Diagram, and (4) Groundwater suitability analysis for irrigation with USSL Diagram. Data collection was carried out temporally for 13 times, from February 2019 to January 2020. The parameters observed were electrical conductivity (EC, measured directly in the field using EC meters) and several major elements, i.e., $\mathrm{Ca}^{2+}, \mathrm{Mg}^{2+}$, $\mathrm{Na}^{+}$, and $\mathrm{K}^{+}$, which were analyzed in the laboratory.

Percent sodium content was calculated using equation 1 . It represents the percent sodium content in groundwater compared to other cations and is expressed in meq/l. The calculation results were then grouped into five classes (Table 1) to determine the suitability of water for irrigation purposes.

$$
N a \%=\frac{(N a+K) 100}{(C a+M g+N a+K)}
$$

Table 1. Classification of Groundwater Suitability Level for Irrigation Based on Percent

\begin{tabular}{|c|c|c|}
\multicolumn{4}{c}{ Sodium Content $(\mathrm{Na} \%)$} \\
\hline Classification & $\mathbf{N a} \%$ & Class of Water \\
\hline S1 & $<20$ & Excellent \\
\hline S2 & $20-40$ & Good \\
\hline S3 & $40-60$ & Permissible \\
\hline S4 & $60-80$ & Doubtful \\
\hline S5 & $>80$ & Unsuitable \\
\hline
\end{tabular}

Source: Wilcox (1955) [23]

Sodium Adsorption Ratio (SAR) was computed using equation 2. All cations used in this calculation are presented in meq/liter. The calculation results were then classified according to the provision listed in Table 2. 


$$
S A R=\frac{N a}{\sqrt{\frac{1}{2}(C a+M g)}}
$$

Table 2. Classification of Groundwater Suitability Level for Irrigation Based on SAR Values

\begin{tabular}{|c|c|c|}
\hline Classification & SAR & Class of Water \\
\hline S1 & $<10$ & Excellent \\
\hline S2 & $10-18$ & Good \\
\hline S3 & $18-26$ & Fair \\
\hline S4 & $>26$ & Poor \\
\hline
\end{tabular}

Source: Bhat et al. (2018) [7]

Groundwater suitability for irrigation using the Wilcox diagram was determined by connecting two parameters, namely electrical conductivity and sodium level in groundwater. The Wilcox diagram divides the suitability into five classes, namely excellent to good, good to permissible, permissible to doubtful, doubtful to unsuitable, and unsuitable [7]. Meanwhile, groundwater suitability analysis for irrigation using the USSL diagram was carried out with the same principles as plotting the data on the Wilcox Diagram, only salinity hazard and sodium hazard were the parameters used here. The results of data plotting on the USSL diagram were classified into several suitability classes according to the conditions described in Table 3.

Table 3. Classification of Groundwater Adjustable for Irrigation Based on the USSL Diagram

\begin{tabular}{|c|c|c|c|c|}
\hline C/S & S1 & S2 & S3 & S4 \\
\hline C1 & Good & Moderate to good & Moderate & Moderate to poor \\
\hline C2 & Moderate to good & Moderate & $\begin{array}{c}\text { Moderate to } \\
\text { poor }\end{array}$ & Poor \\
\hline C3 & Moderate & Moderate to poor & Poor & Very poor \\
\hline C4 & Moderate to poor & Poor & Very poor & Unusable \\
\hline
\end{tabular}

Source: USSL (1954) [24]

\section{Results and Discussion}

The electrical conductivity, as measured directly in the field, showed a somewhat widely temporal variation (Table 4) between the rainy season and the dry season. Electrical conductivity tended to be higher in the dry season (April 2019-October 2019) than in the rainy season. This is possible because, in the dry season, Gremeng Resurgence receives recharge water only from groundwater as allogenic recharge and diffuse flow as autogenic recharge [20]. Meanwhile, in the rainy season, dilution by rain reduces dissolved solids in groundwater; hence, a relatively low electrical conductivity.

Table 4. The Measurement Results of Water Suitability Parameters for Irrigation in Gremeng Resurgence

\begin{tabular}{|c|r|r|r|r|r|}
\hline \multirow{2}{*}{ Date } & \multicolumn{4}{|c|}{ Major Ion (meq/L) } & \multirow{2}{*}{ EC $(\boldsymbol{\mu S})$} \\
\cline { 2 - 5 } & $\mathbf{C a}^{2+}$ & $\mathbf{M g}^{\mathbf{2}}$ & \multicolumn{1}{|c|}{$\mathbf{N a}^{+}$} & \multicolumn{1}{c|}{$\mathbf{K}+$} & 215 \\
\hline $02 / 22 / 2019$ & 1.95 & 0.36 & 0.43 & 0.08 & 215 \\
\hline
\end{tabular}




\begin{tabular}{|l|l|l|l|l|l|}
$03 / 12 / 2019$ & 1.50 & 0.32 & 0.43 & 0.05 & 213 \\
\hline $03 / 25 / 2019$ & 1.65 & 0.52 & 0.39 & 0.05 & 234 \\
\hline $03 / 25 / 2019$ & 2.00 & 0.72 & 0.39 & 0.05 & 249 \\
\hline $04 / 07 / 2019$ & 2.40 & 0.72 & 0.52 & 0.05 & 247 \\
\hline $05 / 07 / 2019$ & 3.19 & 0.72 & 0.43 & 0.05 & 268 \\
\hline $07 / 13 / 2019$ & 3.29 & 0.68 & 0.70 & 0.05 & 280 \\
\hline $08 / 04 / 2019$ & 3.74 & 0.28 & 0.30 & 0.03 & 373 \\
\hline $09 / 20 / 2019$ & 2.91 & 1.48 & 0.83 & 0.05 & 339 \\
\hline $10 / 22 / 2019$ & 1.80 & 1.20 & 0.78 & 0.05 & 359 \\
\hline $11 / 25 / 2019$ & 2.51 & 1.62 & 0.89 & 0.02 & 387 \\
\hline $12 / 29 / 2019$ & 1.88 & 0.72 & 0.65 & 0.08 & 265 \\
\hline $01 / 27 / 2020$ & 1.99 & 0.56 & 0.65 & 0.03 & 270 \\
\hline
\end{tabular}

Source: Field Survey and Laboratory Analysis

Table 4 also shows that not every major ion content in Gremeng Resurgence had a wide temporal fluctuation, for example, magnesium, sodium, and potassium. A high variation was only found in calcium ions, which is inevitable because calcium and bicarbonate are the primary ions composing karst regions. Calcium was found to be higher in the dry season, indicating the absence of dilution process but prevailing water-rock interaction.

Relatively small fluctuations in major ion content were also apparent in groundwater suitability levels for irrigation that did not fluctuate drastically and tended to be relatively stable (Table 5). Classification by SAR proved that the groundwater suitability levels for irrigation fell into the category of Excellent throughout the year. A different condition was detected in $\mathrm{Na} \%$, which classified groundwater suitability as good to excellent. Nevertheless, the percent sodium in good was only slightly higher than $20 \%$, i.e., $21 \%$. A decline in suitability class came about during the rainy season (Figure 3 ). A low sodium concentration (less than 20\%) indicates that the threat of soil damages due to sodium is also low. Sodium can damage soil structure, which consequently decreases infiltration capacity, forms hard soil crust, and inhibits crop growth $[25,26]$.

Table 5. The Calculation Results of $\mathrm{Na} \%$ and SAR of Gremeng Resurgence

\begin{tabular}{|l|r|c|r|c|}
\hline \multicolumn{1}{|c|}{ Date } & $\mathbf{N a \%}$ & $\begin{array}{c}\text { Classification of } \\
\text { Na\% for Irrigation }\end{array}$ & \multicolumn{1}{c|}{ SAR } & $\begin{array}{c}\text { Classification of } \\
\text { SAR for } \\
\text { Irrigation }\end{array}$ \\
\hline $02 / 22 / 2019$ & 18.18 & Excellent & 0.41 & Excellent \\
\hline $03 / 12 / 2019$ & 21.12 & Good & 0.46 & Excellent \\
\hline $03 / 25 / 2019$ & 16.98 & Excellent & 0.38 & Excellent \\
\hline $03 / 25 / 2019$ & 14.03 & Excellent & 0.34 & Excellent \\
\hline $4 / 7 / 2019$ & 15.52 & Excellent & 0.42 & Excellent \\
\hline $05 / 07 / 2019$ & 11.06 & Excellent & 0.31 & Excellent \\
\hline $07 / 13 / 2019$ & 15.83 & Excellent & 0.49 & Excellent \\
\hline $08 / 04 / 2019$ & 7.58 & Excellent & 0.21 & Excellent \\
\hline $09 / 20 / 2019$ & 16.65 & Excellent & 0.56 & Excellent \\
\hline $10 / 22 / 2019$ & 21.78 & Good & 0.64 & Excellent \\
\hline $11 / 25 / 2019$ & 17.96 & Excellent & 0.62 & Excellent \\
\hline $12 / 29 / 2019$ & 21.95 & Good & 0.57 & Excellent \\
\hline $01 / 27 / 2020$ & 21.05 & Good & 0.58 & Excellent \\
\hline
\end{tabular}

Source: Data Analysis Results (2020)

The results showed by two previous methods and the Wilcox Diagram were similar (Figure 4). The Wilcox diagram analysis revealed that the suitability of karst groundwater in Gremeng Resurgence for irrigation fell into the category of excellent to good. In other words, hazards that originate from sodium presence and electrical conductivity in the study area are relatively low. Such low electrical conductivity is attributable to the relatively long distance 
to seawater sources (little to no possibility of intrusion), relatively small catchment (13.25 $\mathrm{km}^{2}$ ), allogenic recharge that responds quickly to rain (allowing short contact of water to rocks), and relatively developed dissolution channels [27, 28, 29]. High electrical conductivity has the same impact as high sodium content. Both can lead to the deaths of crops or non-optimum crop growth in agricultural land.

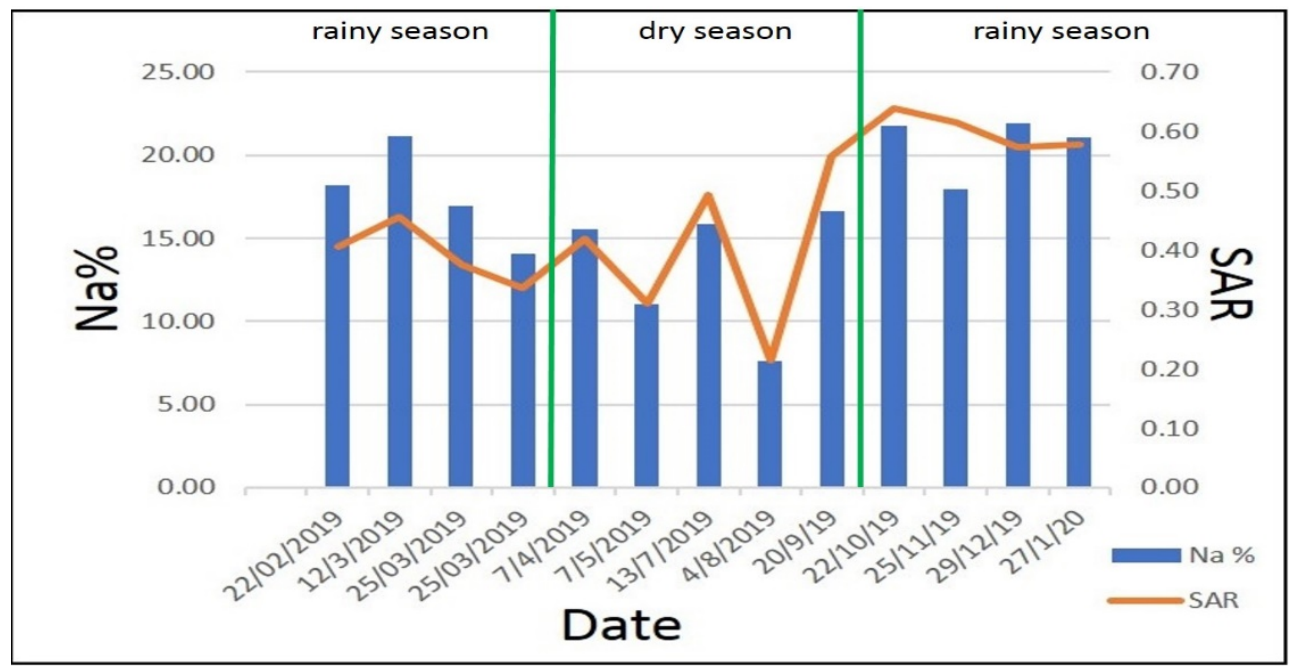

Figure 3. Temporal Variation of $\mathrm{Na} \%$ and SAR in Gremeng Resurgence

Although both Wilcox and USSL diagrams of Gremeng Resurgence (Figures 4 and 5) showed that the danger level of sodium was low (Figure 3), the salinity hazards detected were different. These results are possible because the classification of salinity hazards in the USSL diagram has a shorter range than that of the Wilcox diagram. In the USSL diagram, the classes are limited to $250 \mu \mathrm{S} / \mathrm{cm}, 750 \mu \mathrm{S} / \mathrm{cm}$, and $2250 \mu \mathrm{S} / \mathrm{cm}$ electrical conductivities, whereas in the Wilcox diagram, the ranges of electrical conductivities in every class are much wider, namely $1000 \mu \mathrm{S} / \mathrm{cm}, 2000 \mu \mathrm{S} / \mathrm{cm}, 3000 \mu \mathrm{S} / \mathrm{cm}$, and $5000 \mu \mathrm{S} / \mathrm{cm}$.

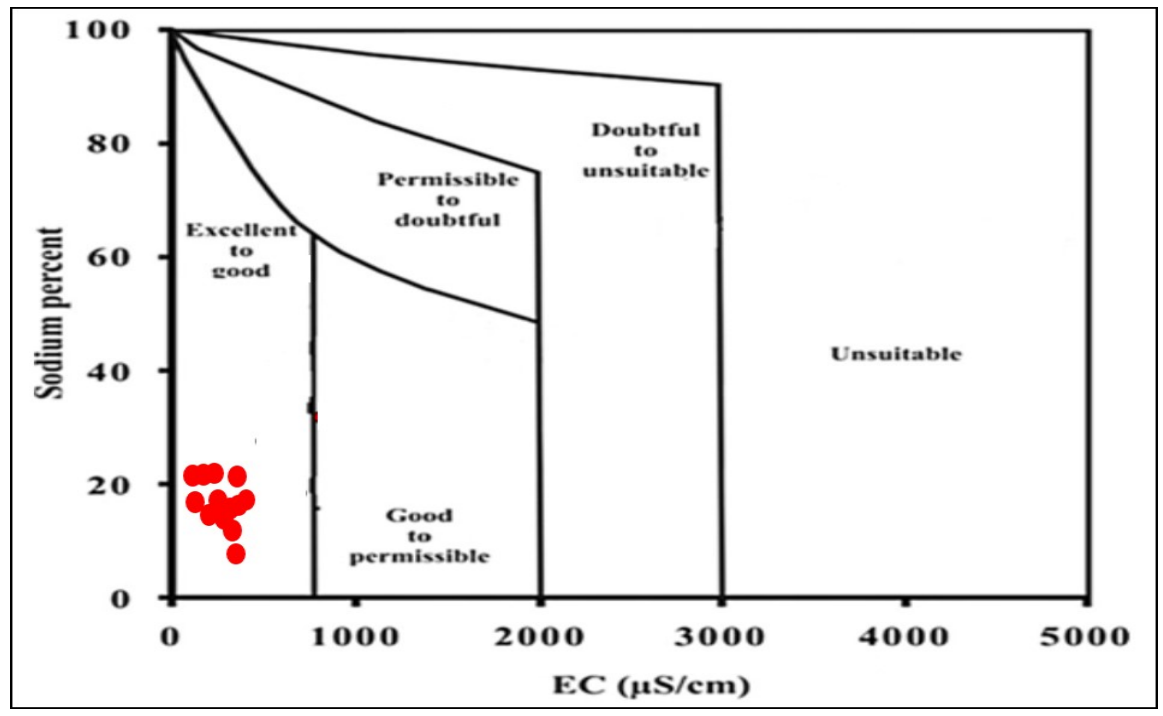


Figure 4. The Suitability of Gremeng Resurgence Water for Irrigation Based on the Wilcox Diagram

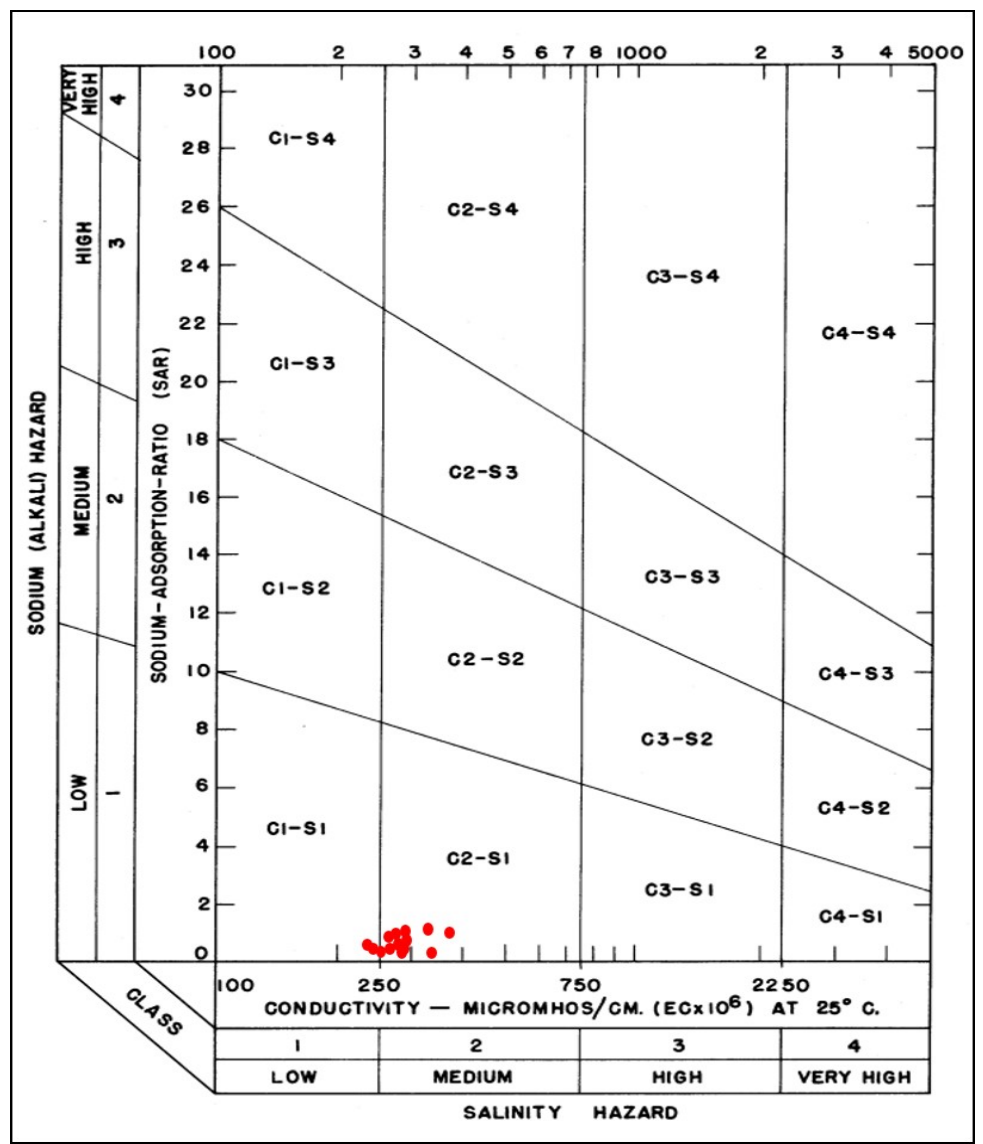

Figure 5. The Suitability of Gremeng Resurgence Water for Irrigation Based on the USSL Diagram

\section{Conclusion}

The season is a factor of groundwater quality characteristics and, consequently, temporal variation of groundwater quality in Gremeng Resurgence. During the rainy season, dilution by rainwater that enters the groundwater through allogenic recharge and flows through dissolution conduits reduces the water quality slightly. On the contrary, during the dry season, the water-rock interaction process becomes dominant. Nevertheless, the groundwater quality parameters in the study area do not vary widely so that the class of groundwater suitability for irrigation does not change significantly. Such temporal variations show that groundwater suitability for irrigation changes only between good and excellent classes, while the salinity hazard levels range from low to medium. Overall, the groundwater in Gremeng Resurgence is suitable for irrigation purposes throughout the year.

\section{Acknowledgment}


This research uses some of the data analyzed and presented in the first author's dissertation. It received funding from Universitas Gadjah Mada through the Grant Scheme for Final Assignment Recognition Program (Hibah Program Rekognisi Tugas Akhir) in 2020, with the contract number 2607/UN1/DITLIT/DIT-LIT/PT/2020.

\section{References}

[1] Alexakis, D., \& Tsakiris, G. Drought impacts on karstic spring annual water potential. Application on Almyros (Heraklion Crete) brackish spring. Desalination and Water Treatment, 16, 1-9 (2010)

[2] Zouhari, A., Dakak, H., Douaik, A., El Khadir, M. and Moussadek, R. Evaluation of Groundwater Sutitability for Irrigation in the Skhirat Region, Northwest of Maroco. Environmental Monitoring and Assessment, 187: 4184 (2015)

[3] Wada, Y., van Beek, L.P.H. and Bierkens, M.F.P. Nonsuitable Groundwater Sustaining Irrigation: A Global Assessment. Water Resources Research, 48, W00L06, (2012)

[4] Abdullah, K. B. Use of Water and Land for food security and Environmental Sustainability. Irrigation and Drainage, 55: 219 - 222 (2006)

[5] Shiklomanov, I.A. World Water Resources and Water Use: Present Assessment and Outlook for 2025. in Rijsberman, F.R. (ed) World Water Scenarios Analyses. Earthscan, London (2000)

[6] Vörösmarty, C.J., Leveque, C. and Revenga C. Chapter 7: Freshwater Ecosystems. in Boss, R., Caudill, C., Chilton, J., Douglas, E.M., Meybeck, M., Prager, D., Balvanera, P., Barker, S., Maas, M., Nilsson, C., Oki, T. and Reidy, C.A. Millennium Ecosystem Assessment, vol. 1, Conditions and Trends, 165-207. Island Press, Washington, D. C. (2005)

[7] Bhat, M.A., Wani, S.A., Sungh, V.K., Sahoo, J., Tomar, D. and Sanswal, R. An Overview of the Assessment of Groundwater Quality for Irrigation. Journal of Agriculture Science and Food Research, 9(1): 1-9 (2018)

[8] Narany, T.S., Ramli, M.F., Aris, A.Z., Sulaiman, W.N.A., and Fakharian, K. Groundwater Irrigation Quality Mapping using Geostatistical Techniques in Amol-Babol Plain, Iran. Arabian Journal of Geoscience, 8: 961 - 976 (2015)

[9] Subba, R.N., Prakasa, R.J., Devadas, J.D., Srinivasa. R.K.V., Krishna, C., Nagamalleswara, R.B. Hydrogeochemistry and Groundwater Quality in a Developing Urban Environment of a Semi-Arid Region, Guntur, Andhra Pradesh, India. Journal of the Geological Society of India, 59, 159-166 (2002)

[10] Taheri, M., Gharaie, M.H.M., Mehrzad, J., Afshari, R., and Datta, S. Hydrogeochemical and Isotopic Evaluation of Arsenic Contaminated Waters in an Argillic Alteration Zone. Journal of Geochemical Exploration, 175, 1-10, (2017)

[11] Chaudhary, V. and Satheeshkumar, S. Assessment of Groundwater Quality for Drinking and Irrigation Purposes in Arid Areas of Rajastan, India. Applied Water Science, 8, 218 (2018). https://doi.org/10.1007/s13201-018-0865-9

[12] Khalid, S. An Assessment of Groundwater Quality for Irrigation and Drinking Purposes Around Brick Kilns in Three Districts of Balochistan Province, Pakistan, through Water Quality Index and Multivariate Statistical Approaches. Journal of Geochemical Exploration, 197, 14-26 (2019)

[13] Xu, P., feng, W., Qian, H., and Zhang, Q. Hydrogeochemical Characterization and Irrigation Quality Assessment of Shallow Groundwater in the Central-Western Guanzhong Basin, China. International Journal of Environmental Research and Public Health, 16, 1492. (2019) https://doi.org/10.3390/ijerph16091492

[14] Appelo, C.A.J. and Postma, D. Geochemistry, Groundwater and Pollution (2nd ed.). Balkema, Rotterdam, the Netherlands (2005) 
[15] Jayaprakash, M., Giridharan, L., Venugopal, T., Kumar, S.P.K. and Periakali, P. Characterization and Evaluation of the Factors Affecting the Geochemistry of Groundwater in Neyveli, Tamil Nadu, India. Environmental Geology, 54: 855-867 (2008)

[16] Reddy, K.S. Assessment of Groundwater Quality for Irrigation of Bhaskar Rao Kunta Watershed, Nalgonda District, India. International Journal of Water Resources and Environmental Engineering, 5: 418-425 (2013)

[17] Delgado, C., Pacheo, J., Cabrera, A., Batllori, E., Orellana, R., Bautista, F. Quality of Groundwater for Irrigation in Tropical Karst Environment: The Cas of Yucatán, Mexico. Agricultural Water Management, 97: 1423 - 1433 (2010)

[18] Arsland, H. Determination of Temporal and Spatial Variability of Groundwater Irrigation Quality using Geostatistical Techniques on the Coastal Aquifer of Çarşamba Plain, Turkey, from 1990 to 2012. Environmental Earth Sciences, 76, 38 (2017). Doi https://doi.org/10.1007/s12665-016-6375-x

[19] Haryono, E., Barianto, D.H. and Cahyadi, A. Hidrogeologi Kawasan Karst Gunungsewu: Panduan Lapangan Fieldtrip PIT PAAI ke-2. Yogyakarta: Perhimpunan Ahli Airtanah Indonesia (PAAI) (2017)

[20] Cahyadi, A., Haryono, E., Adji, T,N., Widyastuti, M., Riyanto, I.A., Naufal, M., and Ramadhan, F. Allogenic River in the Hydrogeological System of Gremeng Cave, Gunungsewu Karst Area, Java Island, Indonesia. IOP Conference Series Earth and Environmental Science, 448(1), 012018 (2020)

[21] Ayers, R.S. and Westcot, D.W. Water Quality for Agriculture. FAO Irrigation and Drainage Paper, 29(1), 1-130 (1994)

[22] Hem, J.D. Study and Interpretation of the Chemical Characteristics of Natural Water. USGS, Water Supply Paper, 2254: 117-120 (1985)

[23] Wilcox, L.V., Classification and Use of Irrigation Use. US. Dept. Agric, 969. Washington, D.C., 40 pp. (1955)

[24] USSL. Diagnosis and Improvement of Saline and Alkali Soils: US Department of Agriculture (USDA), Handbook No. 60, pp:160 (1954)

[25] Todd, D. K. Groundwater Hydrology. Wiley, New York (1980)

[26] Santos, F.L., Reis, J.L., Martins, O.C., Castanheira, N.L. and Serralheiro, R.P. Comparative Assessment of Infiltration, Runoff and Erosion of Sprinkler Irrigated Soils. Biosystems Engineering, 86: 355-364 (2003)

[27] Cahyadi, A., Riyanto, I.A. and Naufal, M. Karakterisasi Sistem Hidrologi Mataair Gremeng, Ponjong, Gunungkidul Berdasarkan Uji Perunutan (Tracer Test). Research Report. Yogyakarta, Universitas Gadjah Mada (2019)

[28] Ramadhan, F., Widyastuti, M., Adji, T.N. Cahyadi, A., Naufal, M., Riyanto, I.A. IOP Conferences Series: Earth and Environmental Science, 451(1), 012060 (2020)

[29] Naufal, M., Widyastuti, M., Cahyadi, A., Ramadhan, F., Riyanto, I.A., Adji, T.N. and Haryono, E. Temporal Variations of Baseflow Contribution to Epikarst Spring Discharge in Gunungsewu Karst Area, Indonesia. e3s-Conference, 125, 01014 (2020) 